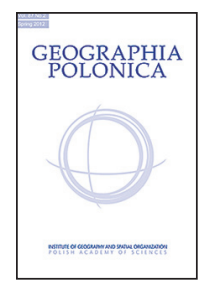

\title{
TRANSBORDER RELATIONS BETWEEN TERRITORIAL UNITS IN THE POLISH-GERMAN BORDERLAND
}

\section{Sylwia Dołzbłasz}

\author{
University of Wrocław \\ Institute of Geography and Regional Development \\ Kuźnicza 49/55, 50-138 Wrocław: Poland \\ e-mail address: sylwia.dolzblasz@uni.wroc.pl
}

\begin{abstract}
The aim of the study was to analyse transborder relations at the local level in the Polish-German borderland. In order to describe the character of the relations, all the communes (gmina) in the Polish part of the borderland and all the districts (Kreise) in the German part have been examined. An additional aim of the analysis was to answer the question as to whether, in the relations between Polish and German territorial units, a co-operative or competitive attitude is prevailing. To this end, a questionnaire survey was conducted (in April 2011) among the local-government authorities in the Polish-German borderland. The area under investigation is comprised of communes (NUTS5) belonging to the districts neighbouring the Polish side of the border, and districts (NUTS3) situated along the German side of the border. On the basis of empirical data, the intensity of the level of co-operation has been evaluated. The study also allowed us to determine the impact of co-operation on borderland areas. Furthermore, the effects in different fields (i.e. socio-cultural, economic, infrastructural), have been analyzed. The selected results that were obtained were then compared to analogous research conducted in 2003.
\end{abstract}

\section{Key words}

transborder relations - cross-border co-operation - transborder competition

- borderland region - Polish-German borderland

\section{Introduction}

The article concerns relationship shaping in border areas. There are many unique phenomena and processes that are characteristic of border areas, and which usually do not occur further inland. When the border is open, the inhabitants of the border regions of one country have the opportunity to use the services available on the other side of the border on a daily basis. Commuting to work or school across the border is commonplace. The enterprises operating in border regions have the opportunity to collaborate with companies from the other side of the border. Thus, they are also under increased competitive pressure from economic entities of the neighbouring country. Similarly, territorial units have to take into account various conditions resulting from their location in the vicinity of the country border as well as from the proximity of local and regional units of the neighbouring country. Due to a very wide range of conditions resulting from the location at the countries' border, the relationships between the inhabitants, territorial units and enterprises may take different forms. These relationships range from open hostility to full co-operation within 
a functional transborder region. In each border region throughout Europe these relationships fit somewhere in between these two extremes. It needs to be remembered, though, that they may have a different character within a region, depending on the type of entity, or the aspect that is under examination.

With regard to the relationships between local governments, it needs to be stressed that location in the border region offers additional development opportunities (e.g. proximity to the market of a neighbouring country). At the same time, however, it may pose a threat to the development of territorial units. What is characteristic of border regions is the co-occurrence of both relationships of co-operation as well as competition. The objective of this study was to determine the character of the relationships between Polish and German territorial units from the Polish-German border region.
This study focuses on the answer to the question whether the relationships between Polish and German local governments are dominated by co-operation or competition. The other purposes were as follows:

- to describe the character of relationships,

- to evaluate the intensity of co-operation,

- to evaluate the level of competitive pressure,

- to describe the effects of co-operation.

Furthermore, the study aimed to analyse the spatial aspect of the existing relationships and identify mutual dependencies between the analysed features.

The study was conducted in the region of the Polish-German borderland (Fig. 1), which for the purposes of this study is defined as an amalgamation of two districts (powiat) on the Polish side, and on the German side it is composed of one district (due to its size) running along Polish-German border. The empirical analysis was based on the

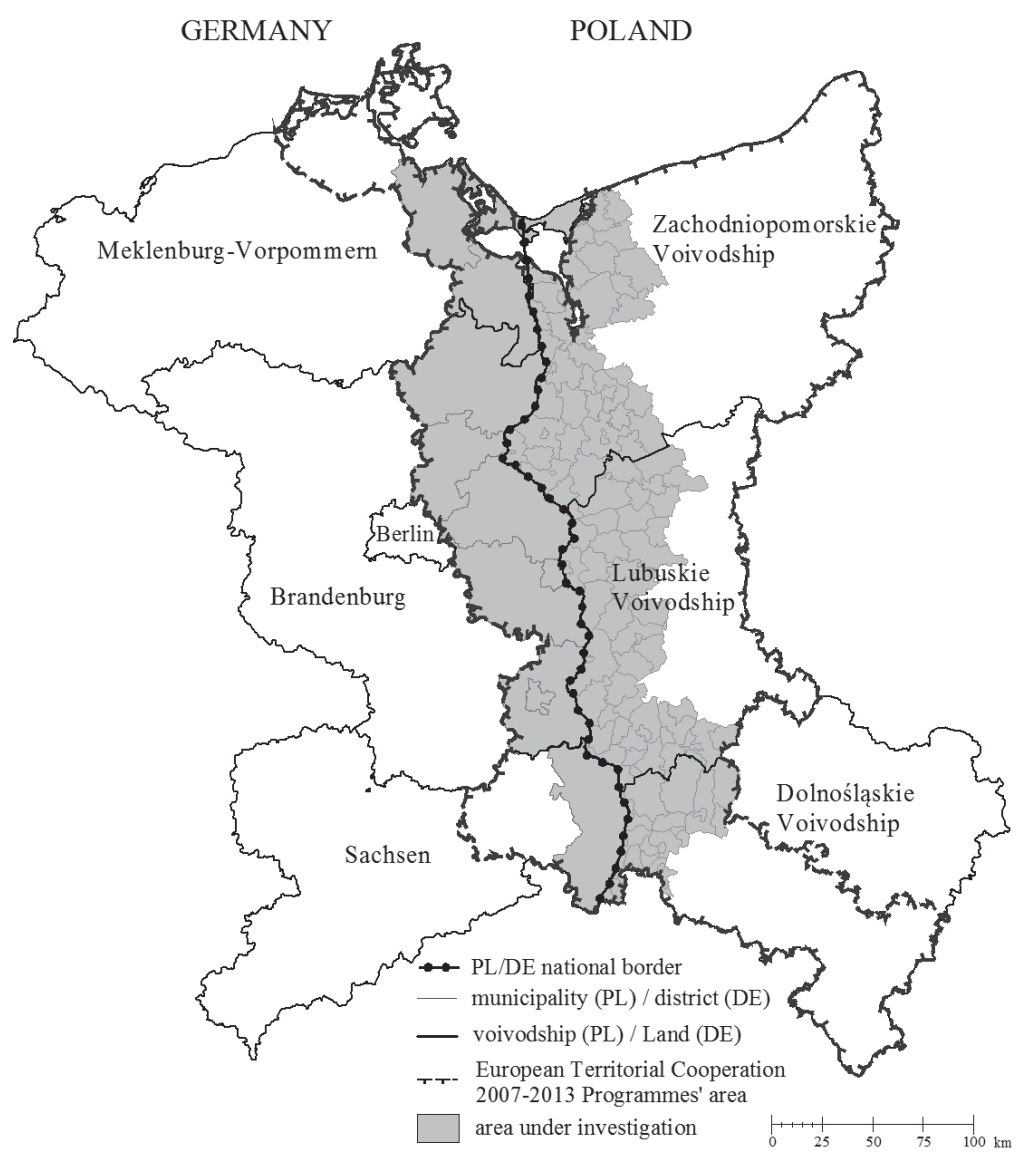

Figure 1. Area of the study. 
results of a survey carried out among territorial government units. On the Polish side it covered units of a commune level (LAU2), and on the German side those of Kreise (NUTS3). Such a choice of units resulted from the author's intention to compare territorial units running local development policy which those that have a similar scope of competence. The author is aware that they differ in size, but this choice was dictated by a relative comparability in terms of competence.

The study was conducted in April 2011 and was preceded by a pilot study. About $60 \%$ of the questionnaires were returned from the total number of 115 sent (among the Polish respondents, the number of questionnaires returned were slightly fewer than among the German respondents). Selected features were compared with the results of analogous research carried out in 2003. This paper is part of a broader study of the relationships that exist in the Polish-German borderland. Additionally, this study analysed the assessment of selected aspects of the competitiveness of territorial units in the context of the cross-border neighbourhood and the relationships between enterprises in the border region.

\section{Co-operation and competition in borderlands}

Borders are, by nature, areas of contradiction with many aspects: gates and barriers, protection and trapping, safety and danger, contact and conflict, identification and differentiation, and lastly, co-operation and competition. With time, these apparent dichotomies can intertwine, but they can also co-exist in the same people or co-function within the same institutions, some of which deal with the space of two neighbouring countries on a regular basis (Anderson \& O'Dowd 1999).

Similarly, borderlands, due to their special character, are areas that encompass the co-existence of relationships of co-operation as well as competition. These relationships may intensify as well as weaken over time. The elimination of a number of barriers facilitates the establishment and realization of transborder co-operation in various spheres (e.g. political, economic, social etc.). At the same time it increases the competitive pressure from the neighbouring areas in the borderland. This concerns, in particular, the shaping of the competitiveness of territorial units and economic entities.
The subject of transborder co-operation and the development of a borderland area is a complex one. This means that it is a very interesting, vast and interdisciplinary research area (Brunet-Jailly 2005; Newman \& Paasi 1998). It is a relatively new research area in fields such as economic geography, economics, political sciences, sociology, and regional policy. In the discussion concerning borders and borderlands, from the point of view of the geographical sciences, we can distinguish a number of research trends, e.g. studies concerning terminological issues (Minghi 1963; Prescott 1965; Newman \& Paasi 1998), the classification of borders (Hartshorne 1936; Kristof 1959), issues that concern the evolution of borders and the effect that these changes have on the development of border areas (Prescott 1967; Ratti et al. 1993) in a number of aspects e.g. the cultural landscape (Leimgrüber 1991; Gallusser 1991), the border identification of the inhabitants (Meinhof \& Galasiński 2002).

Poland and other countries of Central Europe witnessed an increase in interest in the issue of borders and borderlands in the 1990s. This seems to be directly caused by the political transformations in this part of Europe, which began in 1989 and largely affected changes in the role and function of borders and the way borderland areas function in economic, social and spatial senses. The studies of border and borderlands concerned the following issues: the theoretical problems of borders and borderlands shaping (Ciok 1990, 2004; Eberhardt 2004; Moraczewska 2008; Rykiel 1990, 1991, 2006, 2011; Sobczyński 2006), transport connections and the permeability of borders (Komornicki 1999, 2004, 2005), an analysis of the influence of border functions on the shaping of processes and phenomena in borderlands (including their influence on the everyday life of inhabitants; Ciok 1979; Gorzelak \& Jałowiecki 2001; Heffner 1996; Trosiak 1993), co-operation between economic entities (Stryjakiewicz 1998; Gruchman et al. 2002; Raczyk et al. 2012), the transborder openness of companies in a divided city (Dołzbłasz \& Raczyk 2012), disparities in the standard of living (Ciok et al. 2008; Miszczuk 2008), socio-cultural issues in a broad sense (Szul 2005, 2008), or environmental conditions (Więckowski 2004) and the development of tourism (Więckowski 2010). Furthermore, there were a number of studies which approached the problem from a social point of view, e.g. stereotypes, 
language issues, ethnic and national minorities (Dębicki 2010; Kurcz \& Sakson 2009), political science analyses in the aspect of governance etc. (Jańczak 2008), or the network of co-operation of subnational units (Dumała 2012). At present, (trans) border co-operation is a very popular phenomenon. In the field of geography, the issue of Poland's transborder co-operation with neighbouring countries has been documented in a relatively extensive literature. The studies usually focus upon particular geographic areas (e.g. euroregion, voivodeship, city) or thematic scopes. In the first group, most studies have analysed co-operation with Germany, which mainly results from the development of institutional connections that have continued over a long period (Ciok 1990, 2004; Stryjakiewicz 1996; Gorzelak et al. 2004; Węcławowicz et al. 2006). A relatively large number of studies have been devoted to co-operation with Russia, Belarus and Ukraine (Miszczuk \& Kawałko 2005; Miszczuk 2007; Komornicki 2008; Palmowski 2007a, b). The analyses concerning the southern border have focused mainly on its environmental and tourist aspects (Więckowski 2004; Potocki 2010). Very little attention has been devoted to analysing the Polish-Lithuanian borderland (Misiak \& Rejzner 2002). Moreover, only a few studies have been concerned with a complex assessment of the effects of the realization of the integration idea in terms of its social, economic and spatial aspects (Gorzelak et al. 2004; Gorzelak \& Krok 2006; Krok \& Smętkowski 2006; Dołzbłasz \& Raczyk 2010a).

It must be stressed that the amount of research into the processes and relationships in the borderlands is increasing. As Newman and Paasi have observed (1998: 197) "state borders are at the same time social, political and discursive concepts, and not just statistical categories situated between countries". Apart from the spatial dimension, today's border is understood in a much broader sense, no longer as a merely physical barrier separating one country from the other, but as a socio-spatial construction exhibiting and voicing the existing diversities (Van Houtum 2005). Yet, the issue of dependence between the two relationships existing in the borderland and the shaping of transborder regions has not to date been thoroughly analysed.

The studies conducted so far concerning the dependencies between the relationships of competition and co-operation were mainly conducted with regard to economic entities. Therefore, they mainly take into account the company context. Although the mechanisms of co-operation and competition between territorial settings may generally shape in a similar way, one needs to consider their specificity resulting from formal-legal conditions and different, objective possibilities, and the scope of co-operation and competition.

It needs to be stressed that the theory, practice as well as the scale of the research relating to the planning and strategic management of various institutions was for many years dominated by the paradigm of competition. An alternative, relatively new paradigm of co-operation indicates that the world consists of a network of mutual relationships that have developed and supported the process of co-operation in order to achieve mutual benefits. Each of these perspectives only partly accounts for the actual situation. Therefore, according to many researchers it is necessary to synthesize the two approaches (Lado et al. 1997).

\section{Determinants of co-operation and competition in the Polish- -German borderland}

The relationships in the Polish-German border region are shaped by many different factors. This multi-faceted character includes political, economic, social, historical and environmental conditions (Dołzbłasz \& Raczyk 2010a). Among the political conditions, the most important seem to be the border and the Good-Neighbourhood Treaties (Dziennik Ustaw 1992a, b), both Germany and Poland's membership of the European Union, and the gradual opening of the borders. Certainly, joint participation in an integration group (including Poland's accession to the Schengen Zone in 2007) is an element that positively influences Polish-German relations. It is also connected with the realization of transborder co-operation programmes in previous years within Phare CBC, Interreg IIIA, and presently within European Territorial Cooperation. The network of connections is mainly created by institutional actors (communes, districts). Although it is difficult to assess the effects of the implementation of transborder co-operation projects, it is generally thought to be very positive in many respects, and certainly contributes to, among other things, the reduction of cultural or infrastructural barriers (Dołzbłasz \& Raczyk 2010b). It should also be noted that in the service sector it is mainly the Pol- 
ish entities that are open to clients from the other side of the border. Among German companies, the level of openness is much lower (Dołzbłasz \& Raczyk 2012).

Although there are still barriers in Polish-German relations, this tendency is decreasing in many areas within the Polish-German border regions. The cultural barrier between the two communities is relatively high, and is a consequence of negative historical experiences, the existence of negative stereotypes, or attitudes and perception of the neighbouring nation (Krätke 2002; Leibenath \& Knippschild 2005; Meinhof \& Galasiński 2005; Kurcz \& Sakson 2009). The language barrier is still very significant (Jańczak 2009; Wilkinson 2009). It needs to be stressed that these types of cultural barrier are decreasing, especially among young people (due to, for example, the opening of borders and high transborder mobility, which enable mutual knowledge of the two communities; language skills; and also simply the passage of time). Mutual relationships may also be made difficult by the fact that the inhabitants of the Polish border regions, who were originally immigrants, do not identify themselves fully with the place, which may lead to a decrease in local activity, such as transborder co-operation (Dołzbłasz \& Raczyk 2011). It also seems that this barrier should be decreasing, since the regional/local identity of the members of the younger generations should be connected with the so-called Recovered Territories, and not the land from which the settlers arrived after the war. This element is connected with the feeling of injustice felt by the Germans, which resulted from the displacement of their population from these regions. It is worth mentioning that the level of social capital in the western border region is lower than the average for Poland (with the exception of local activity areas, e.g. Koszalin and Szczecin districts; Janc 2007), which is not conducive to the activity in the fields of transborder co-operation. Historical conditioning, which on the one hand creates a barrier, also at the same time creates the foundations for co-operation when it comes to cultivating the cultural heritage of the borderland or sentimental tourism.

Among economic conditions, disparities in the level of socio-economic development on both sides of the border are one of the most significant factors. It seems that the high level of these disparities is an important factor hindering co-operation and generating competition. Moreover, due to the character of border areas both on the Polish and the German side, there are numerous obstacles to socio-economic development. These barriers result mainly from the relatively low level of development in the border areas (when compared to the average in Germany and Poland) and are also the effect of the peripheral geographical situation of both the German and Polish parts of the borderland. The occurrence of disparities can be observed both on the national scale (periphery - centre) as well as internationally (Polish versus German borderland). An important factor is the difference in income, which is much lower on the Polish side. It leads to a number of consequences, such as higher labour costs in Germany. However, the unemployment situation is much better on the Polish side. In this context, one needs to mention a marked decrease in the size of the population in the German border region, which is both the result of the negative birth rate and the migration of inhabitants, especially among the younger age groups. As far as economic conditions are concerned, one should not forget about the price level, which is generally lower on the Polish side (however, a trend towards price levelling can be observed on both sides of the border) (Dołzbłasz \& Raczyk 2012).

Among the environmental conditions, the most important is undoubtedly the character of the country's border. The river character of the border (it runs mostly along the Oder and the Lusatian Neisse) in practice turns out to be a considerable barrier, significantly limiting the free flow of people and goods. Considerable financial outlays, mainly connected with the construction of bridges, are needed if this is to be overcome. The formal elimination of border crossings following Poland's entry into the Schengen Zone offers the theoretical possibility of crossing the border in any place. However, in the case of the Polish-German border, this does not significantly help due to the small number of river crossings. A particular improvement has been noticeable in the northern section, where the border runs on land and here we can indeed observe some signs of creating a true transborder region, e.g. the inflow of Polish citizens to the border towns on the German side and the daily commuting to work in Szczecin, or the free transfer of tourist and sanatorium patients from Świnoujście to nearby German towns, and similar activities in the opposite direction. It should be noted that the border river could be a factor that encourages co-operation - for example in environmental 
protection, natural disaster prevention, economic initiatives, and finally the development of tourism based on the Oder. Unfortunately, the potential of the Oder is not being used, neither in the context of the economic development of Poland, nor of the Polish-German borderland.

\section{Characteristics of transborder relations}

For the purposes of this study, an analysis of the transborder relations was performed on selected features of joint Polish-German linkages at the local level. Thus, the research into transborder relations covered Polish territorial units (commune; gmina) as well as German ones (district; Kreise) from the Polish-German borderland.

As far as the intensity of co-operation and the competition in the Polish-German borderland is concerned it was clearly noticeable that the responses among Polish local governments were more varied than those of their German counterparts (Fig. 2). The vast majority of the German poviats assessed the level of co-operation as being intensive. Half of the Polish local governments, however, claimed that the level of co-operation with the German units was intensive or very intensive, and the other half maintained that the level of intensity was low or very low. Most Polish local governments did not feel too much competitive pressure from German territorial units. On the German side, however, the competitive pressure from their Polish neighbours was perceived as being strong (nearly $50 \%$ of the respondents). It seems that this mainly resulted from economic conditions, e.g. lower labour costs, incentives for investors on the Polish side of the borderland, as well as a relatively difficult economic situation on the German side. There are marked differences in the way Polish and German units perceive their mutual relationships: the German side assesses them as stronger, which concerns both the sphere of co-operation and competition. This could result from the fact that the vast majority of the German units recognized the Polish side (in general) and consequently were able to define their relationships. Moreover, probably the German local authorities are more aware of the significance of co-operation with other territorial units, including those on the other side of the border. On the Polish side, however, in a large number of communes, the foreign perspective in the shaping of local devel- opment tends to be incorporated only to a very limited extent. A characteristic feature is that German local authorities assessed their relations with their Polish counterparts as being stronger than in the opinion of Polish local governments, both with regard to cooperation and competition. This indicates an asymmetry in the perception of the analysed elements.

The different types of relationships between Polish and German local governments in the Polish-German borderland were shaped differently depending on the country of origin of the respondents (Fig. 3). Among the German units there was a strong conviction that the relationships with their Polish neighbours are mostly based on partial co-operation, with competition in economic terms. A positive aspect was a relatively high percentage of responses reporting strong relationships. A clear example of this is the common competition of the Polish and German partners against other units. It seems that the relationship is particularly 'advanced', which indicates a partial shaping of the borderland as a Polish-German functional region. German units, in contrast to the Polish communes, did not report a co-operation-oriented
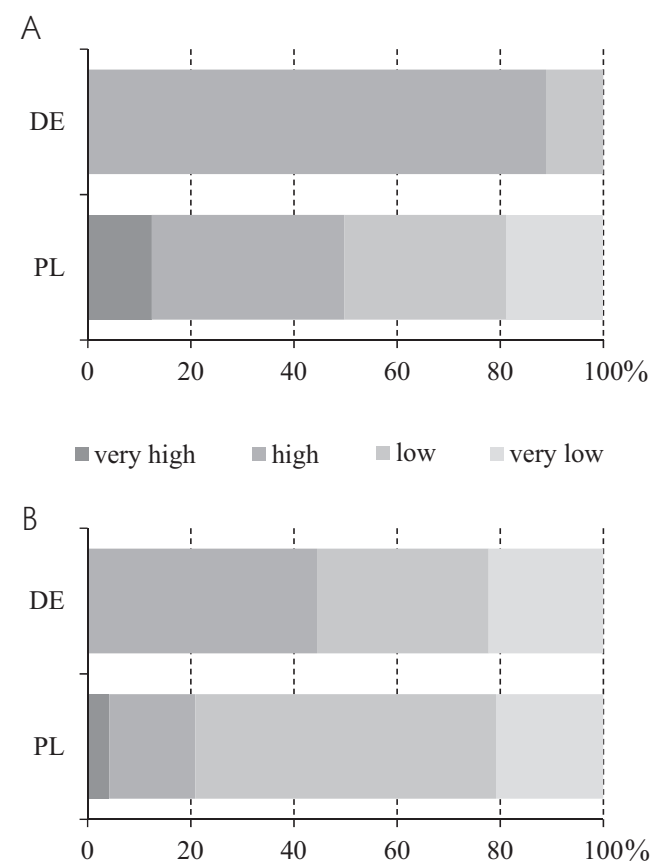

Figure 2. Intensity of co-operation (A) and the level of competitive pressure (B) between Polish and German territorial units in the Polish-German borderland in 2011. 


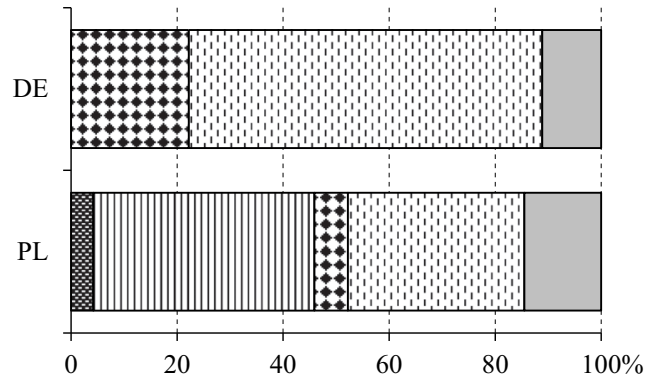

⿴囗十 predominance of competitive relations

$\square$ predominance of cooperative relations

@ competing jointly with third party

$\square$ partial cooperation but competition in economic field

$\square$ none of above

Figure 3. Types of relationships between Polish and German self-government units in the Polish-German borderland in 2011.

relationship, which was the most common answer among Polish respondents. It should be emphasised that the German districts, when assessing Polish-German relationships, nearly always indicated the existence of competition, either partial - as in between Polish and German units - or joint competition against units from outside the borderland. It is certainly connected with a stronger perception of competitive pressure by the German territorial units (Fig. 2).

If we compare the dominant Polish-German relationships in 2003 and 2011 we will see characteristic changes in the assessments of Polish communes (Fig. 4). An important element of these changes was a clear increase in co-operation-dominated relationships. The respondents, who in 2003 were unable to define the type of relationships between the Polish and German units, in 2011 defined this relationship as mainly co-operation-orientated. This seems to be the result of a significant intensification of transborder projects (as far as the numbers and finances are concerned) caused by the implementation of Interreg III A programmes following Poland's accession to the EU in 2004.

There is a clear interdependence between the intensity of co-operation and the level of competitive pressure among Polish communes situated

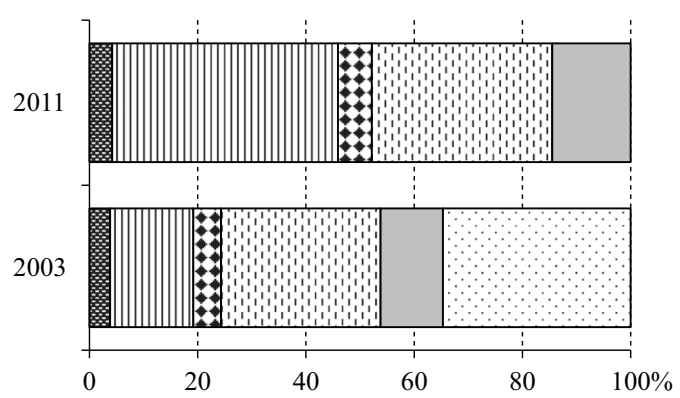

⿴囗大 predominance of competitive relations

$\mathbb{\square}$ predominance of cooperative relations

$\boldsymbol{\square}$ competing jointly with third party

$\square$ partial cooperation but competition in economic field

$\square$ none of above

$\square$ lack of answer

Figure 4. Types of relationships between Polish and German territorial units in the Polish-German borderland according to Polish communes in 2003 and 2011.

in the Polish-German border region (Fig. 5). The greater the intensity of co-operation, the more perceptible the competitive pressure is. It can be concluded that there is a group among the communes that is strongly connected with the German units, both in terms of co-operation as well as competition. On the other hand, there are some other communes which have no connections with

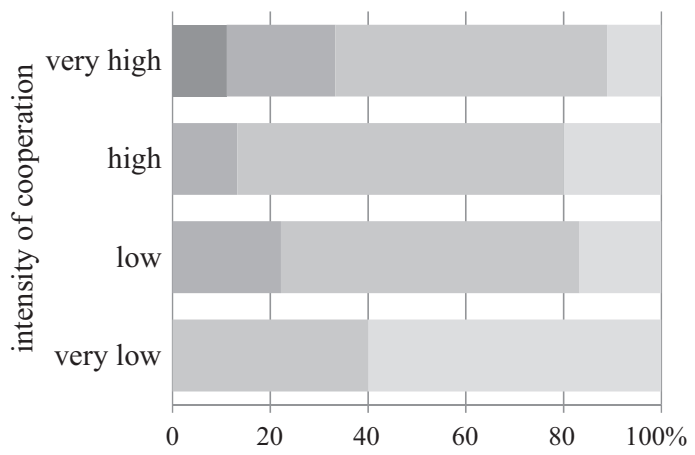

level of competitive pressure

घery high $\quad$ high $\quad$ low $\quad$ very low

Figure 5. Co-operation and competition between Polish and German territorial units in the Polish-German borderland in 2011. 
the German side, and are neither co-operating nor competing. Apart from these two extremes, there is of course a group of communes which display mixed relationships.

In the perception of both Polish as well as German local governments the effects of co-operation between them are very diverse (Fig. 6). Local governments pointed to the effects in the field of infrastructure, economy, culture as well as the mental sphere. The strongest effects were observed in joint Polish-German cultural and tourist events. It needs to be stressed that the Polish as well as the German sides have noticed a decrease in negative stereotypes. However, there are no apparent effects in the sphere of investment, the implementation of best practice, or knowledge improvement. In the economic sphere, the relatively strong effects in co-operation between businesses are perceived as being positive. The greatest divergences in the responses of the Polish and German local governments were observed during the strategic documents' consulting and technology transfer. In the case of the strategic documents' consulting these differences may result from greater pressure from the German side on this type of activities in terms of the scope of spatial and strategic planning; and the improvement of the Polish side in this sphere. In the case of technology transfer, it seems that German municipal governments recognize the positive effects of technological progress on the Polish side.

It should be noted that the strongest relationships were observed in the regions supported within the Interreg IIIA and ETC programmes. In contrast, the weakest relationships were observed in those areas which are directly connected with the shaping of local policy (e.g. development plans, development strategies); and territorial units may relatively easily co-operate in these spheres. In principle, the directions of co-operation result from the expenditure structure within the Interreg IIIA and ETC. The units were directed to a lesser extent (especially on the Polish side) by the tasks which are important from the point of view of local development, which may also have a permanent character (e.g. best-practice implementation in the management of territorial government units or territorial marketing). Local governments preferred to support the activities which produce a relatively swift and visible effect rather than those that are long-term

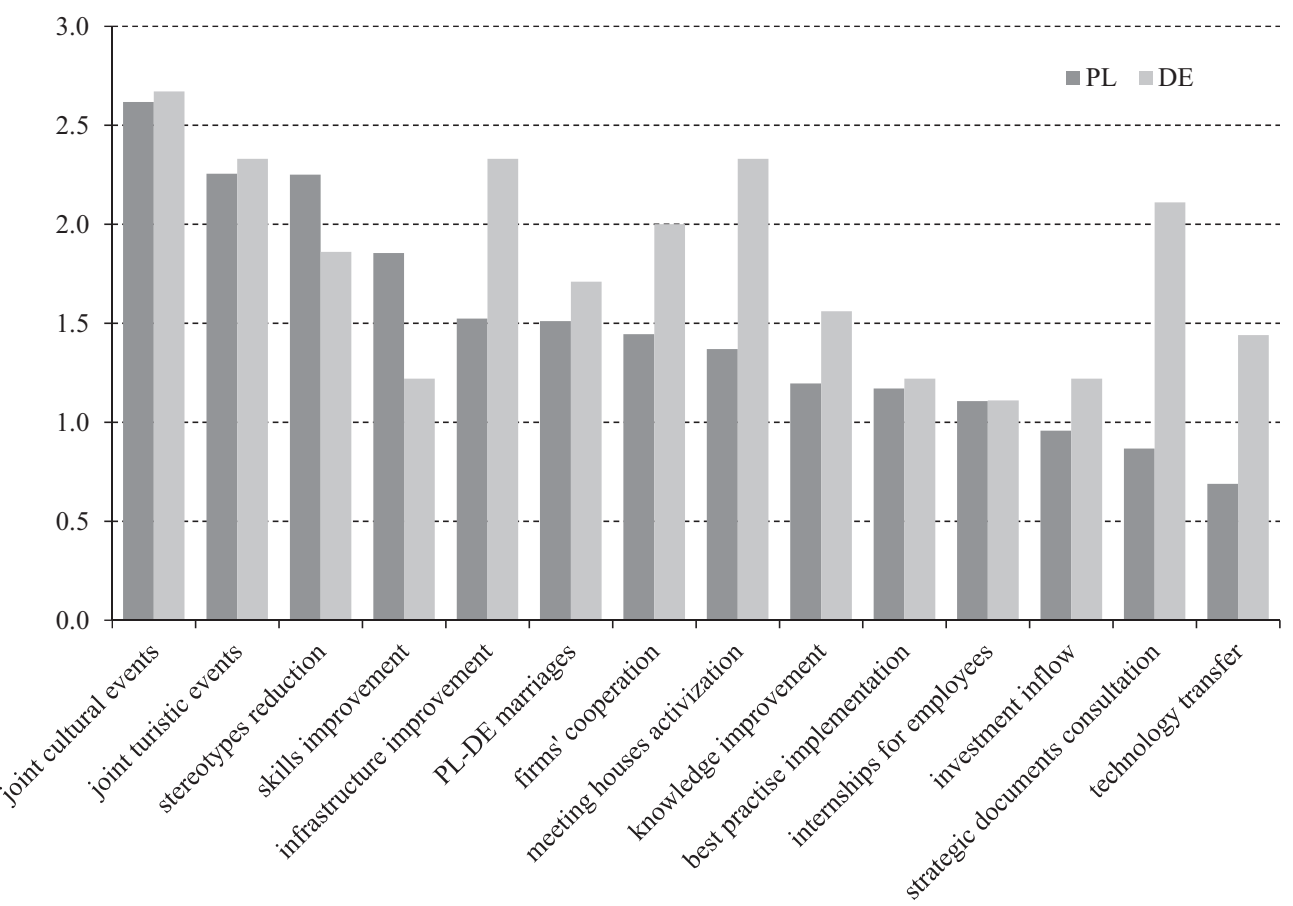

Figure 6. Effects of co-operation between Polish and German territorial units in the Polish-German borderland in 2011. 

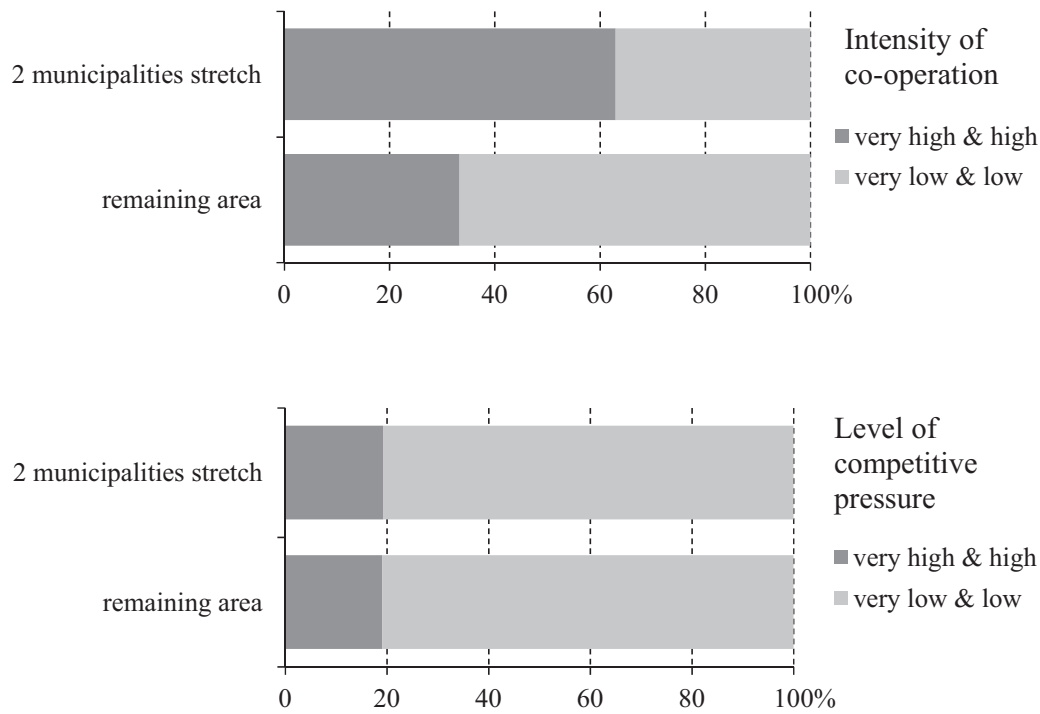

Figure 7. Intensity of co-operation and level of competitive pressure in Polish communes by location in the Polish-German border area (second commune stretch from the border).

and connected with changes in the functioning of these institutions.

Considering the relationship between the analysed phenomena and the location of the communes in the Polish border region, the interdependencies were observed only in relation to some features (Fig. 7).

It was clear that the intensity of co-operation was greater in the communes located closer to the Polish-German border (within the stretch of two communes from the border). Those situated further from the border showed less involvement when it came to co-operation with partners from the German side of the border region. However, location near the border did not affect the level of competitive pressure felt by the Polish local governments.
Similarly, the types of relationships between Polish local authorities from the border region with their German counterparts had little effect on the type of competitive pressure that was perceived. Among units situated within the stretch of the two communes from the border, the percentage of responses reporting the dominance of co-operative relationships and those of joint competition against units from outside the borderland was only slightly higher than in the communes situated in the remaining part of the borderland.

A strong degree of interdependence, however, was observed in relation to the effects of co-operation. In the communes located closer to the Polish-German border they were much stronger than in the communes located further away from the border (Fig. 8).

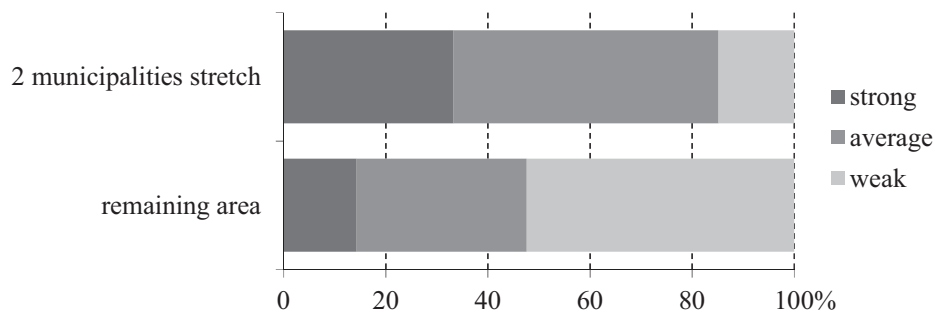

Figure 8. Effects of co-operation in the opinion of Polish communes by location in the Polish-German border area. 
This results from the fact that in the communes directly neighbouring the German units the co-operation was stronger, and consequently its effects were more visible. Moreover, these units, due to their proximity to the border and their connections with the neighbourhood of the German communes and districts, often have to co-operate in order to be able to perform the regular activities of the commune. As a result, the relationships of the two communities are on the one hand more frequent, and on the other, more practical.

\section{Conclusions}

On the basis of the conducted study it was concluded that, in the assessment of the units of territorial government at the local level, in the Polish-German border region both relationships of co-operation as well as competition can be observed. On the Polish side the percentage of co-operative relations was slightly higher, but the intensity of co-operation was assessed as similar by both Polish and German local governments. It was clearly visible that among German local units the competitive pressure from the neighbours across the border was more keenly felt than among the Polish communes. The question of whether the relationships of the Polish and German governments are dominated by the attitude of co-operation or competition cannot be answered unambiguously. The results of the analysis indicate that there is no dominance of either co-operation or competition. It needs to be stated that these attitudes are rather 'mixed', especially due to the considerable significance of the attitude of partial co-operation accompanied by competition in the economic sphere (this is especially strong on the German side). A positive element was certainly the relatively large presence of 'advanced' relations whose aim was joint Polish-German competition against other units. It should be noted that there is a clear increase in the participation of this type of relationships when compared to that of 2003.

The occurrence of both the attitudes of cooperation and competition is a very important observation in terms of transborder region shaping (understood as a functional region). This confirms the research of other authors showing the above regularity (Church \& Reid 1996; Luo 2004). This situation creates very favourable conditions for integration in the German-Polish borderland. The main reason for the changes identified in 2003 and 2011 was certainly Poland's accession to the EU. It had a significant impact on the Polish and German local governments in the border area, both in terms of territorial competitiveness and mutual relations. For the most part it was associated with the possibility of obtaining EU funds and the implementation of projects within the Structural Funds and Cross-border Cooperation Programmes (Interreg III 2004-2006, ETC 2007-2013). The observed regularities were largely forced by external circumstances and were not the result of deliberate action on the part of local governments in the framework of the development programming process. Therefore, it is difficult to speak of a 'new quality' of cooperation and competition on the Polish-German borderland (though the increase in the intensity of cross-border relations was observed). The study indicates that the behaviour of local authorities was partly passive in nature (i.e. they respond to changing conditions), and not the result of systemic, comprehensive changes in the policy of cooperation, competition and development of the border area.

It is a characteristic of the Polish border region that one can find communes which have strong ties with German units (either based on co-operation or competition). On the other hand, there are communes for which the fact of neighbouring Germany hardly matters, and their geographical situation in the border region has virtually no effect on the daily functioning of these government units. A location that is in close proximity to the German-Polish border (a stretch of two communes) significantly affected both the intensity of co-operation with German local governments and its effects. No such interdependence was, however, observed in the case of competitive pressure from the German units. It could have resulted from the fact that on the whole Polish communes in the border region did not feel too much of pressure from the German side.

Based on the survey it can be seen that the real extent of transborder relations is conditioned by distance from the border, as the 'transborder perspective' is important mainly in the narrow stretch of one or two communes from the national border (when it comes to the Polish side). This indicates that the real extent of transborder relations should be taken into account in the scientific research (e.g. the delimitation of the border area) as well as in the cross-border cooperation policy implementation. Moreover, it can be 
observed that, despite many years of activities aiming at the development of the Polish-German borderland (most often defined as a subregions or even regions/Länder adjacent to the border) the area that has real links/connections across the border is very limited. A characteristic feature is the very large diversity of the intensity of cross-border relations within borderland. This is due to the presence of outstanding areas of strong cooperative and competitive relations. However, their identification and detailed analysis require a separate in-depth study.

\section{References}

ANDERSON J., O'Dowd L., 1999. Borders, border regions and territoriality: Contradictory meanings, changing significance. Regional Studies, vol. 33, no. 7, pp. 593 $-604$.

Brunet-Jallly E., 2005. Theorizing borders: An interdisciplinary perspective. Geopolitics, vol. 10, no. 4, pp. 633-649.

Church A., Reid P., 1996. Urban power, international networks and competition: The example of cross-border cooperation. Urban Studies, vol. 33, no. 8, pp. 1297-1318.

CIÉ́LIK A., 2005. Location of foreign firms and national border effects: The case of Poland, Tijdschrift voor Economische en Sociale Geografie, vol. 96, no. 3, pp. 287-297.

Ciok S., 1979. Zmiany funkcji granicy i jej wpływ na przeobrażenia w strefie przygranicznej (na przykładzie rejonu Zgorzelca). [in:] B. Winiarski, M. Musiał, M. Klamut (eds.), Rozwój społeczno-ekonomiczny obszarów przygranicznych. Wrocław: Komisja Nauk Ekonomicznych PAN, Ossolineum, pp. 211-233.

Cıok S., 1990. Problematyka obszarów przygranicznych Polski Południowo-Zachodniej. Studium społeczno-ekonomiczne. Acta Universitatis Wratislaviensis, no. 1155, Studia Geograficzne, vol. 48, Warszawa-Wrocław: Wydawnictwo Uniwersytetu Wrocławskiego, $150 \mathrm{pp}$.

Ciok S., 2004. Pogranicze polsko-niemieckie. Problemy współpracy transgranicznej. Wrocław: Wydawnictwo Uniwersytetu Wrocławskiego, 260 pp.

Ciok S., Leśniak M., Dołzbłasz S., Raczyk A., 2008. Polska-Niemcy. Współpraca i konkurencja na pograniczu. Acta Universitatis Wratislaviensis, no. 3064, Studia Geograficzne, vol. 81, Wrocław: Wydawnictwo Uniwersytetu Wrocławskiego, 214 pp.

\section{Acknowledgements}

A research paper financed from the 2009-2011 budget under the Ministry of Science and Higher Education project No 4299/PB/IGRR/09 entitled: "The shaping of co-operation and competition relationships in the Polish-German border regions as part of European integration".

Editor's note:

Unless otherwise stated, the sources of tables and figures are the author, on the basis of their own research.

DęiCKI M., 2010. Stereotypy Czechów wobec Polaków na pograniczu - regionalne zróżnicowanie oraz determinanty stanu rzeczy. Acta Universitatis Wratislaviensis, no. 3265, Socjologia, vol. 50, Wrocław: Wydawnictwo Uniwersytetu Wrocławskiego, 222 pp.

DoŁZBŁASZ S., RACZYK, A., 2010a. Współpraca transgraniczna w Polsce po akcesji do UE. Warszawa: Wolters Kluwer Polska, 240 pp.

DoŁZBŁASZ S., RACZYK A., 2010b. The role of the integrating factor in the shaping of transborder co-operation: The case of Poland. Quaestiones Geographicae, vol. 29, no. 4, pp. 65-73.

DoŁzBŁAsZ S., RaczYK A., 2011. Projekty współpracy transgranicznej na zewnętrznych i wewnętrznych granicach Unii Europejskiej - przykład Polski. Studia Regionalne i Lokalne, no. 3(45), pp. 59-80.

DoŁZBŁASZ S., RACZYK A., 2012. Transborder openness of companies in a divided city: Zgorzelec/Görlitz case study. Tijdschrift voor Economische en Sociale Geografie, vol. 103, no. 3, pp. 347-361.

DüRRSCHMIDT J. 2010. Between Eurpeanization and Marginalization - "Nested Urbanism" in a German-Polish Border Town. [in:] M. Nowak, M. Nowosielski (eds.), Declining cities/developing cities: Polish and German perspectives, Poznań: Instytut Zachodni, pp. 221-232.

DumaŁA H., 2012. Transnarodowe sieci terytorialne w Europie. Lublin: Wydawnictwo Uniwersytetu Marii Curie-Skłodowskiej, 459 pp.

DZIENNIK USTAW, 1992a. Traktat między Rzeczapospolita Polska a Republika Federalna Niemiec o potwierdzeniu istniejacej między nimi granicy, podpisany dnia 14 listopada 1990 r. Dziennik Ustaw Rzeczypospolitej Polskiej, 1992, nr 14, poz. 54.

DzIENNIK UstaW, 1992b. Traktat między Rzeczapospolita Polska a Republika Federalna Niemiec o dobrym sasiedztwie i przyjaznej współpracy, podpisany dnia 
17 czerwca 1991 r. Dziennik Ustaw Rzeczypospolitej Polskiej, 1992, nr 14, poz. 56.

EBERHARDT P., 2004. Polska i jej granice. Z historii polskiej geografii politycznej. Lublin: Wydawnictwo Uniwersytetu Marii Curie-Skłodowskiej, 302 pp.

FaŁkowski M., 2003. Polska jako Wschód i Zachód. Wzajemne postrzeganie Polaków i Niemców - wyniki najnowszych badań. [in:] B. Kerski (ed.), Saqsiedztwo w centrum Europy. Stosunki polsko-niemieckie na początku nowego stulecia. Antologia tekstów Magazynu Polsko-Niemieckiego Dialog z lat 1999-2003, Polsko-Niemiecka Biblioteka Szczecińska, Szczecin-Berlin: Instytut Niemiec i Europy Północnej, Wyższa Szkoła Administracji Publicznej, Federalny Zwiq̨zek Towarzystw Niemiecko-Polskich, pp. 38-46.

GalAsińSKA A., GALAsIŃSKI D., 2003. Discursive strategies for coping with sensitive topics of the Other. Journal of Ethnic and Migration Studies, vol. 29, no. 5 , pp. 849-863.

Gallusser W.A., 1991. Geographical investigation in boundary areas of the Basel Region ("Regio"). [in:] D. Rumley, J.V. Minghi (eds.), The geography of border landscapes. London-New York: Routledge, pp. 31-42.

Gorzelak G., Bachtler J., Kasprzyk M. (eds.), 2004. Współpraca transgraniczna Unii Europejskiej. Doświadczenia polsko-niemieckie. Warszawa: Wydawnictwo Naukowe Scholar, Centrum Europejskich Studiów Regionalnych i Lokalnych UW, 378 pp.

GorzelAK G., JatoWIECKI B., 2001. Europejskie granice: jedność czy podział kontynentu? Studia Regionalne i Lokalne, no. 2-3(6), pp. 51-70.

Gorzelak G., Krok K. (eds.), 2006. Nowe granice Unii Europejskiej - współpraca czy wykluczenie? Warszawa: Wydawnictwo Naukowe Scholar, Centrum Europejskich Studiów Regionalnych i Lokalnych, 270 pp.

Gruchman B., Nowińska-Łaźniewska E., Parowicz I., Kötzle A., Huskobla G., Osiecka A. 2002. Współpraca transgraniczna przedsiębiorstw na pograniczu polsko-niemieckim na przykładzie województw zachodniopomorskiego i lubuskiego oraz Landu Brandenburgii. Studia Regionalne i Lokalne, no. 4(10), pp. 23-48.

HARTSHORNE R., 1936. Suggestion on the terminology of political boundaries. Annals of the Association of American Geographers, vol. 26, iss. 1, pp. 56-57.

Heffner K., 1996. Regiony przygraniczne. Zmieniajaca się rola granicy od bariery do katalizatora rozwoju. [in:] K. Heffner (ed.), Region Opawa-Racibórz. Historia i perspektywy w Unii Europejskiej. Materiały z międzynarodowej konferencji w Raciborzu, 12-13 września 1996 roku, Opole: Państwowy Instytut Naukowy - Instytut Śląski, pp. 120-140.

JAŃCZAK J., 2008. Cross-border governance jako podstawa zaawansowanej współpracy polsko-niemieckiej w regionach przygranicznych. [in:] J. Jartyś, A. Staszczyk (eds.), Polityka sąsiedztwa Unii Europejskiej. Pomostowość czy buforowość? Szczecin: Instytut Politologii i Europeistyki Uniwersytetu Szczecińskiego, pp. 207-220.

JAŃCZAK J. (ed.), 2009. Conflict and cooperation in divided cities. Thematicon, no. 14, Berlin: Logos Verlag, $274 \mathrm{pp}$.

JAŃCZAK J., 2011. Chancen und Probleme der grenzüberschreitenden deutsch-polnischen Zusammenarbeit am Beispiel von Zwillingsstädten in Grenzgebieten. Jahrbücher des Föderalismus, vol. 12, Baden-Baden: Nomos Verlagsgesellschaft, Europäisches Zentrum für Föderalismus-Forschung Tübingen, pp. 399-410.

Komornicki, T., 1999. Granice Polski. Analiza zmian przenikalności w latach 1990-1996. Geopolitical Studies, vol. 5, Warszawa: Instytut Geografii i Przestrzennego Zagospodarowania PAN, 346 pp.

KomORNICKI T., 2004. Przemiany przenikalności polskich granic w latach 1990-2002. [in:] T. Markowski (ed.), Przestrzeń w zarządzaniu rozwojem regionalnym i lokalnym. Biuletyn KPZK PAN, no. 211, Warszawa: Komitet Przestrzennego Zagospodarowania Kraju PAN, pp. 391-406.

KOMORNICKI T., 2005. Transport transgraniczny jako pojęcie geograficzne. Prace Komisji Geografii Komunikacji, vol. 11, Warszawa-Rzeszów: Komisja Geografii Komunikacji PTG, Wydział Ekonomii Uniwersytetu Rzeszowskiego, pp. 55-64.

KOMORNICKI T., 2008. Polska granica wschodnia - zmiany w natężeniu, strukturze $i$ kierunkach interakcji w latach 1990-2007. [in:] S. Dołzbłasz, A. Raczyk (eds.), Przekształcenia regionalnych struktur funkcjonalno przestrzennych. Europa bez granic - nowa jakość przestrzeni, Rozprawy Naukowe Instytutu Geografii i Rozwoju Regionalnego Uniwersytetu Wrocławskiego, no. 4, Wrocław: Uniwersytet Wrocławski, pp. 109-120.

KRÄTKE S., BORST R., 2007. EU Eastern enlargement and the configuration of German-Polish inter-firm linkages. Tijdschrift voor Economische en Sociale Geografie, vol. 98, no. 5, pp. 621-640.

KRISTOF K.D., 1959. The Nature of frontiers and boundaries. Annals of the Association of American Geographers, vol. 49, no. 3, pp. 269-282.

Krok K., SmętKowski M. (eds.), 2006. Cross-border co-operation of Poland after EU enlargement. Focus on eastern border. Warszawa: Wydawnictwo Naukowe Scholar, 171 pp.

Kurcz Z., SAKSOn A. (eds.), 2009. Polskie transgranicza. Wrocław: Wydawnictwo Uniwersytetu Wrocławskiego, $151 \mathrm{pp}$.

Lado A.A., Boyd N.G., Hanlon S.C., 1997. Competition, cooperation, and the search for economic rents: 
A syncretic model. The Academy of Management Review, vol. 22, no. 1, pp. 110-141.

LeIBENATH M., KNIPPSCHILD R., 2005. Systemic evaluation of cross-border networks of actors: Experience with a German-Polish-Czech cooperation project. Journal of Borderlands Studies, vol. 20, no. 1, pp. 73-90.

LEIMGRÜBER W., 1991. Boundaries, values and identity: The Swiss-Italian transborder region. [in:] D. Rumley, J.V. Minghi (eds.), The geography of border landscapes, London-New York: Routledge, pp. 43-62.

LEIMGRÜBER W., 2005. Boundaries and transborder relations, or the hole in the prison wall: On the necessity of superfluous limits and boundaries. GeoJournal, vol. 64, iss. 3, pp. 239-248.

Luo Y., 2004. Coopetition in international business. Denmark: Copenhagen Business School Press, 211 pp.

Matthiesen U., Bürkner H.-J., 2001. Antagonistic structures in border areas: Local milieux and local politics in the Polish-German twin city Gubin/Guben. GeoJournal, vol. 54, no. 1, pp. 43-50.

Meinhof U.H, Galasiński D., 2002. Reconfiguring East-West identities: Cross-Generational discourses in German and Polish border communities. Journal of Ethnic and Migration Studies, vol. 28, no. 1, pp. 63-82.

MeINHOF U.H., GalasiŃSKI D., 2005. The language of belonging. Houndmills-Basingstoke-Hampshire-New York: Palgrave Macmillan, 216 pp.

MiNGHI J.V., 1963. Boundary studies in political geography. Annals of the Association of American Geographers, vol. 53, no. 3, pp. 407-428.

Misiak W., Rejzner A. (eds.), 2002. Pogranicze polsko-litewskie. Aktywizacja współpracy, Warszawa: Wydawnictwa Uniwersytetu Warszawskiego, 238 pp.

Miszczuk A., 2007. Zewnętrzna granica Unii Europejskiej - Ukraina. Możliwości wykorzystania dla dynamizacji procesów rozwojowych. [in:] Ekspertyzy wykonane na zamówienie Ministerstwa Rozwoju Regionalnego na potrzeby opracowania "Strategii rozwoju społeczno-gospodarczego Polski Wschodniej do roku 2020". Tom 1, Warszawa: Ministerstwo Rozwoju Regionalnego, pp. 13-70.

Miszczuk A., 2008. Dysproporcje w rozwoju pogranicza polsko-ukraińskiego w warunkach integracji europejskiej. [in:] S. Dołzbłasz, A. Raczyk (eds.), Europa bez granic - nowa jakość przestrzeni, Przekształcenia regionalnych struktur funkcjonalno-przestrzennych. Rozprawy Naukowe Instytutu Geografii i Rozwoju Regionalnego Uniwersytetu Wrocławskiego, no. 4, Wrocław: Uniwersytet Wrocławski, pp. 149-155.

Miszczuk A., Kawatko B. (eds.), 2005. Pogranicze polsko-ukraińskie. Środowisko, społeczeństwo, gospodarka. Zamość: Wyższa Szkoła Zarządzania i Administracji. Centrum Badawczo-Szkoleniowe, 342 pp.
MoraczewskA A., 2008. Transformacja funkcji granic Polski. Lublin: Wydawnictwo Uniwersytetu Marii Curie-Skłodowskiej, 299 pp.

Newman D., PaAsI A., 1998. Fences and neighbours in the postmodern world: Boundary narratives in political geography. Progress in Human Geography, vol. 22, no. 2, pp. 186-207.

Palmowski T., 2007a. Współpraca z Obwodem Kaliningradzkim Federacji Rosyjskiej jako czynnik rozwoju regionalnego. [in:] Ekspertyzy wykonane na zamówienie Ministerstwa Rozwoju Regionalnego na potrzeby opracowania "Strategii rozwoju społeczno-gospodarczego Polski Wschodniej do roku 2020". Tom 1, Warszawa: Ministerstwo Rozwoju Regionalnego, pp. 71-108

Palmowski T. (ed.), 2007b. Pogranicze polsko-rosyjskie. Problemy współpracy transgranicznej z Obwodem Kaliningradzkim. Gdynia-Pelplin: Wydawnictwo Bernardinum, 359 pp.

Ротоскі J., 2010. Funkcje turystyki w kształtowaniu transgranicznego regionu górskiego Sudetów. Wrocław: Wydawnictwo Wrocławskiego Towarzystwa Naukowego, 190 pp.

PRESCOTT J.R.V., 1965. The Geography of frontiers and boundaries. Hutchinson University Library. Geography, no. 96, London: Hutchinson, 190 pp.

RaczYK A., DoŁzBŁasz S., LEŚNIAK-JohanN M., 2012. Relacje współpracy i konkurencji na pograniczu polsko-niemieckim. Wrocław: Gaskor, 375 pp.

RATTI R. 1993. Spatial and economic effect of frontiers. Overview of traditional and new approaches and theories of border area development. [in:] R. Ratti, S. Reichman (eds.), Theory and practice of transborder cooperation. Basel-Frankfurt am Main: Verlag Helbing \& Lichtenhahn, pp. 23-53.

RYKIEL Z., 1990. Region przygraniczny jako przedmiot badań geograficznych. Przegląd Geograficzny, vol. 62, no. 3-4, pp. 263-272.

RYKIEL Z., 1991. Rozwój regionów stykowych w badaniach w teorii i badaniach empirycznych. Prace Habilitacyjne IGiPZ PAN, Warszawa-Wrocław: Instytut Geografii i Przestrzennego Zagospodarowania PAN, Ossolineum, 117 pp.

RYKIEL Z., 2006. Podstawy geografii politycznej. Warszawa: Polskie Wydawnictwo Ekonomiczne, 263 pp.

RYKIEL Z., 2011. Koncepcja pogranicza i peryferii w socjologii i geografii. [in:] B. Jałowiecki, S. Kapralski (eds.), Peryferie i pogranicza. O potrzebie różnorodności. Warszawa: Wydawnictwo Naukowe Scholar, pp. 55-64.

SobczYŃSkI M., 2006. Państwa i terytoria zależne. Ujęcie geograficzno-polityczne, Toruń: Wydawnictwo Adam Marszałek, 541 pp. 
StryakieWICZ T., 1998. The changing role of border zones in the transforming economies of East-Central Europe: The case of Poland. Geojournal, vol. 44, no. 3, pp. 203-213.

SzUL R., 2005. Borders, languages and European integration. [in:] M. Koter, M. Sobczyński (eds.), The role of borderlands in United Europe. The borderlands and integration processes, Region and Regionalism, no. 7, vol. 1-2, Łódź-Opole: University of Łódź Department of Political Geography and Regional Studies, Governmental Research Institute Silesian Institute in Opole, Silesian Institute Society, pp. 7-22.

SzuL R. 2008. Europa bez granic językowych? [in:] D. Ilnicki, K. Janc (eds.), Europa bez granic - nowe wyzwania, Przekształcenia regionalnych struktur funkcjonalno przestrzennych. Rozprawy Naukowe Instytutu Geografii i Rozwoju Regionalnego Uniwersytetu Wrocławskiego, no. 3, Wrocław: Uniwersytet Wrocławski, pp. 19-25.

Trosiak C., 1993. Proces formowania się pogranicza polsko-niemieckiego w latach 1945-1993. Przeglad Zachodni, no. 3, pp. 81-103.
Van Houtum H., 2005. The geopolitics of borders and boundaries. Geopolitics, vol. 10, no. 4, pp. 672-679.

Węctawowicz G., Degórski M., Komornicki T., Korzeń J. (Janusz), Bański J., Korzeń J. (Juliusz), Soja R., ŚleszYŃSKI P., WIĘCKOWSKI M., 2006. Studia nad przestrzennym zagospodarowaniem obszaru wzdłuz granicy polsko-niemieckiej. Prace Geograficzne, no. 207, Warszawa: Instytut Geografii i Przestrzennego Zagospodarowania PAN, 224 pp.

WIĘCKOWSKI M., 2004. Przyrodnicze uwarunkowania kształtowania się polsko-słowackich więzi transgranicznych. Prace Geograficzne, no. 195, Warszawa: Instytut Geografii i Przestrzennego Zagospodarowania PAN, pp. 231.

WIECKOWSKI M., 2010. Tourism development in the borderlands of Poland. Geographia Polonica, vol. 83, no. 2, pp. 67-81.

WILKInSON J., 2009. 'Die härteste Sprachgrenze Europas?' Negotiating the linguistic divide in theatres on the German-Polish border. [in:] J. Carl, P. Stevenson (eds.), Language, discourse and identity in central Europe: The German language in a multilingual space. London: Palgrave Macmillan, pp. 73-95. 